論 文・ Paper

\title{
$\mathrm{CdO} \cdot \mathrm{SiO}_{2} \cdot \mathrm{Na}_{2} \mathrm{O}$ フォトクロミックガラスの光伝導
}

\author{
山本和直・熊田 虔* 並河 洋*

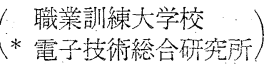

$\mathrm{CdO}$ を含む酸化物ガラスの光伝導とフォトクロミズムの関係を調べるために，47.5 CdO・47.5 $\mathrm{SiO}_{2} \cdot 5 \mathrm{Na}_{2} \mathrm{O}$ ガラスの光電流と光吸収を同一試料で同時に測定した. 顕著な光電流と着色は, とも に吸収端付近の光によって誘起される。生た，着色を誘起する光による光電流には，非常に長い応 答時間をもつ成分が観察される.特に立ち上がり応答に㧍汀る長い応答時間をもつ光電流成分は， 定常值付近を除いて, 着色の大きさと光強度に比例する.

このガラスの光伝導がバンド型の電子伝導であることを前提として，実験結果の解釈を試みた。 ガラス中に含まれる何らかの捕獲中心が光電子を捕えて着色中心を形成し，また捕獲された電子が 光によって伝導帯へ再励起されるとして，光伝導とフォトクロミズムの密接な関係を説明すること ができる．また，電子遷移の確率が 1 分子反応型の速度式に従うと仮定して着色と光電流の立ち上 がり応答を計算すると，計算結果と実験結果はかなり良く一致する。

(1982 年 3 月 3 日受付)

\section{Photoconduction of $\mathrm{CdO} \cdot \mathrm{SiO}_{2} \cdot \mathrm{Na}_{2} \mathrm{O}$ Photochromic Glass}

\author{
Kazunao YAMAMOTO, Ken KUMATA* and Hiroshi NAMIKAWA* \\ $\left(\begin{array}{c}\text { The Institute of Vocational Training } \\ \text { 1960, Aihara, Sagamihara-shi } 229 \\ * \text { Electrotechnical Laboratory }\end{array}\right)$
}

\begin{abstract}
Although appreciable photoconduction can be hardly observed in most oxide glasses, the CdO based glasses exhibit remarkable photoconduction in addition to photochromism, Photoluminescence and thermoluminescence. In order to understand the mechanism of the photoconduction and the photochromism of this type of glass, both the photocurrent and the photoinduced optical absorption were simultaneously measured in a piece of $47.5 \mathrm{CdO} \cdot 47.5 \mathrm{SiO}_{2}$. $5 \mathrm{Na}_{2} \mathrm{O}$ glass by using the specially designed measuring system. This experiment suggested that there is the close relation between the photoconduction and the photochromism as
\end{abstract} follows:

(1) The exposure of the light near the optical absorption edge induces the remarkable photocurrent and coloring.

(2) The increasing photocurrent $\Delta I_{\mathrm{r} \text { is }}$ reaching the steady state value after a very long period of the light exposure time is observed in addition to the initial photocurrent. If the wavelength of the exposure light is constant, $\Delta I_{\text {ris }}$ increases approximately proportional to the optical density change $\triangle O D$ and the light intensity.

These experimental results led us to expect that the photoconduction and the photochromism are induced through the following electronic process.

(1) The exposure of the exciting light near the absorption edge induces the generation of the free electrons in the conduction band by inter band transition.

(2) A part of the free electrons is trapped in some kind of trap center, for instance structural defect, functioning as the color center.

(3) The electrons reexcited thermally or optically from the trap center to the conduction band cause the increasing photocurrent $\Delta I_{\mathrm{ris}}$.

Based on the above mentioned tentative model, the rise curves of the photocurrent and the coloring are calculated by monomolecular equations and compared with the experimental curves. Consequently, it is confirmed that the calculated curves well agree with the experimental curves if the probability of the reexitation is proportional to the internal intensity 
of the exciting light in glass and the density of the trapped electrons. This leads us the conclusion that the most of the trapped electrons are reexcited optically, not thermally.

[Received March 3, 1982]

Key-words : $\mathrm{CdO}$ based oxide glass, $\mathrm{CdO} \cdot \mathrm{SiO}_{2} \cdot \mathrm{Na}_{2} \mathrm{O}$ glass, Photochromic glass, Photoconductive oxide glass, Electronic conducting oxide glass

\section{1. 緒言}

主成分の一つとして $\mathrm{CdO}$ を含む酸化物ガラスは，光 照射に対して幾つかの興味ある応答を示す．酸化物ガラ 久は一般には光伝導を示さないが, Strickler と・Roy ${ }^{1)}$ は各種の重金属を含を酸化物ガラスの光伝導を調べ, $50 \mathrm{~mol} \%$ 以上の $\mathrm{CdO}$ を含卆 $\mathrm{CdO} \cdot \mathrm{SiO}_{2} \cdot \mathrm{B}_{2} \mathrm{O}_{3}$ 亲と $\mathrm{CdO} \cdot \mathrm{GeO}_{2} \cdot \mathrm{B}_{2} \mathrm{O}_{3}$ 系に顕著な光伝導が観察されることを 見いだした。また Meiling ${ }^{2}$ 流, $\mathrm{CdO} \cdot \mathrm{SiO}_{2} \cdot \mathrm{B}_{2} \mathrm{O}_{3}$ 系ガ ラスがフォトクロミズムを示すことを報告している.

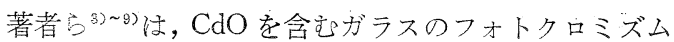
を，もっと広い組成で調い゙る実験を行った。その結果， $50 \mathrm{~mol} \%$ 前後の $\mathrm{CdO}$ を含む $\mathrm{CdO} \cdot \mathrm{SiO}_{2}$ 及び $\mathrm{CdO} \cdot \mathrm{B}_{2} \mathrm{O}_{3}$ 2 成分系, $\mathrm{CdO} \cdot \mathrm{SiO}_{2}$ に数 $\mathrm{mol} \%$ の $\mathrm{Na}_{2} \mathrm{O}, \mathrm{CaO}$ ある いはアルミナを加えた系, 数 $\mathrm{mol} \%$ から約 $30 \mathrm{~mol} \%$ の $\mathrm{CdO}$ を含む $\mathrm{CdO} \cdot \mathrm{GeO}_{2}$ にアルカリ酸化物, アルカリ土 類酸化物あるいはアルミナを加えた系等のガラスが得ら れた. こ礼らのガラスはいずれも吸收端付近の光に対し てフォトクロミズムを示し, 特に $\mathrm{CdO} \cdot \mathrm{GeO}_{2}$ 系に $\mathrm{Tl}_{2} \mathrm{O}$ をドープすると著しい増感効果が認められた ${ }^{8)}$. 更に， フォトクロミズムと同時に光伝導と光ルミネッセンスが 生し，着色したガラスを加熱すると熱ルミネッセンスが 観察された。これら注光電子が関与した現象であると推 定され，これらの現象の間の関係を詳しく調べることに よって，ガラス中での電子の振る舞いやフォトクロミズ ムの機構に関する情報が得られると考えられる.

このような観点から，著者らは $47.5 \mathrm{CdO} \cdot 47.5 \mathrm{SiO}_{2}$ 。 $5 \mathrm{Na}_{2} \mathrm{O}$ ガラスの光電流と光透過率を同一試料で同時に 測定する実験定行った.この実験の結果について, 本諭 文で報管する、はじめに，光伝導とフォトクロミズムの 間に幾つかの密接な関係が見いだされることを示す. 次 に，捕獲中心を含むバンドモデルを用いて，実駼結果の 定性的准解棌を試みる. 最後に，1 分子反応型の速度式 を用いて，光電流と着色の立ち上がり応答を解析する。

\section{1 荼料}

\section{2. 実験，方，法}

ガラスの調合 $\mathrm{mol}$ 組成は, $47.5 \mathrm{CdO} \cdot 47.5 \mathrm{SiO}_{2} \cdot 5$ $\mathrm{Na}_{2} \mathrm{O}$ である. 所定量の原料を $1300^{\circ} \mathrm{C}$ で溶融し，ステ ンレス板上に流し出してガラス化した。 それをガラス転 移点より約 $10^{\circ} \mathrm{C}$ 高い $550^{\circ} \mathrm{C}$ から徐泠した後，厚さ 1.69 $\mathrm{mm}$, 直径約 $25 \mathrm{~mm}$ の円板形に鏡面研磨して測定試料と した.
このガラスに紫外光を照射すると着色する. 着色した ガラス暗中で退色するが, 室温での退色涂極て遅 く, 数日程度で照射前の状態に戻らない.しかしガラ スを $200^{\circ} \mathrm{C}$ 程度に加熱すると数分間で完全に退色し，照 射と加熱を繰り返しても疲労現像隹認められない。この ように加熱によって紫外光照射の残留效果を完全に消し たガラスを, 完全退色ガラスと呼ぶ.

\section{2 光電流之光吸収の同時測定}

光電流と光吸収を同一試料で同時に測定できるよう に，図 1 に示す装置を試作した．図中の点線で囲まれた $\mathrm{E}$ は電流測定のブロック， LE は励起光，LT は光吸収 測定のブロックである.

電極構造は表面型とし，ガラスの片面に図の左上に示 す形状にアルミニウムを蒸着した. 金を半透明潦着し たサンドイッチ型電極による測定も試みたが，この場合 には著しい吸収電流が生に゙た。サンドイッチ型電極の場

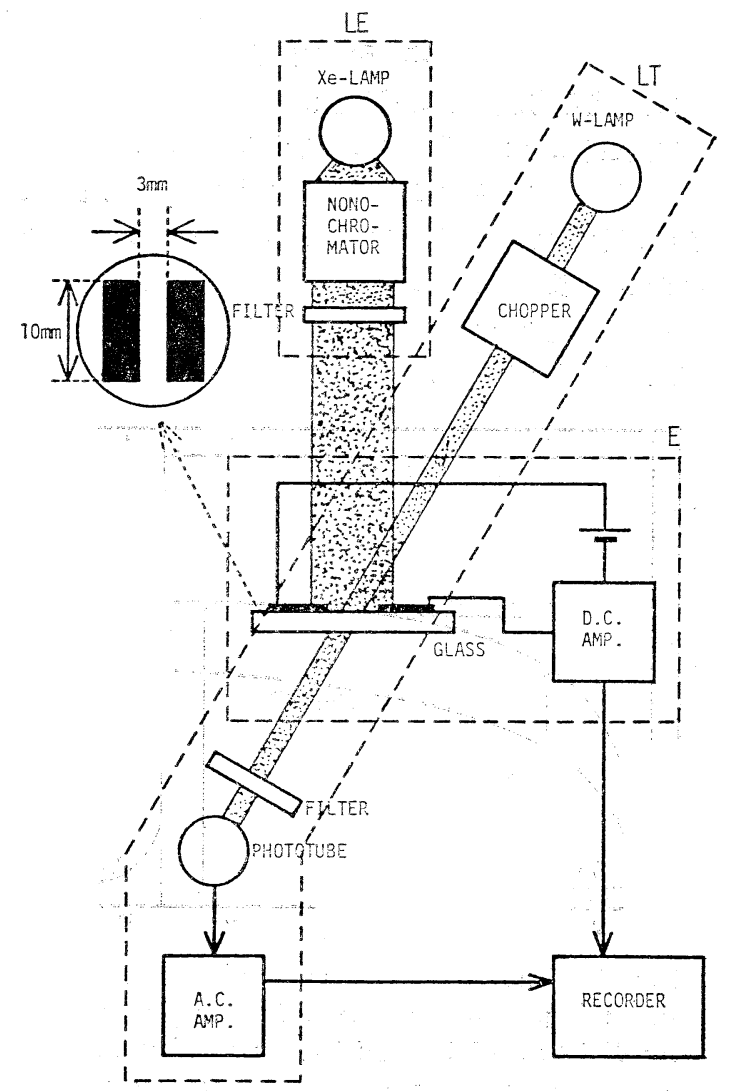

Fig. 1. Photocurrent and optical absorption measuring system. 
合はガラス内の励起光の強度が電場方向に不均一とな り，そのために生じる空間電荷分極がこの吸収電流の原 因であると考えられる。

励起光は $1 \mathrm{~kW}$ のセノンランプの光を回折格子分光 器と 2 次以上の回折光をカットするフィルターに通して 得られる単色光であり，これをガラスの電極側の面に垂 直に照射した. 励起光の強度は波長によって異なるが, ガラスの表面で $0.01 \sim 1 \mathrm{~mW} / \mathrm{cm}^{2}$ の範囲である.

光吸収は波長 $460 \mathrm{~nm}$ で測定した. ガラスを着色させ る光の波長 (約 $350 \mathrm{~nm}$ より短波長) から離れていて, かつ光吸収の変化が十分に大きいという理由からこの波 長を選んだ. 光吸収測定の光源は, 直流安定化電源で点 灯したタングステンランプのごく弱い光を $90 \mathrm{~Hz}$ でチョ ップしたものである。これを入射角 $30^{\circ}$ でガラス面に照 射し, 干渉フィルターで波長 $460 \mathrm{~nm}$ 付近の透過光だけ を取り出して光電管で強度を測定した. チョップした光 源を用いたのは, 光電管から交流成分のみを取り出すこ とによって，迷光によるノイズと光電管の暗電流を除去 できるからである。

広い波長域で吸収スペクトルを調べる場合には，この 装置からガラスを取り出して, 自記分光計を用いて測定 した。 また今回の測定は，すべて室温で行った。

\section{3. 実 験 結 果}

\section{1 光電流と着色の時間変化}

完全退色ガラスに吸収端に対応する約 $350 \mathrm{~nm}$ より短 波長の紫外光を照射すると, 図 2 に示すような光電流と 着色が誘起される. 着色の大きさは, 波長 $460 \mathrm{~nm}$ にお ける光学密度の増加分 $\triangle O D_{460}$ で表した（着色したガラ スと完全退色ガラスの透過率をそれぞれ $T, T_{0}$ とすれ ば, $\triangle O D=\log T_{0} / T$ ).

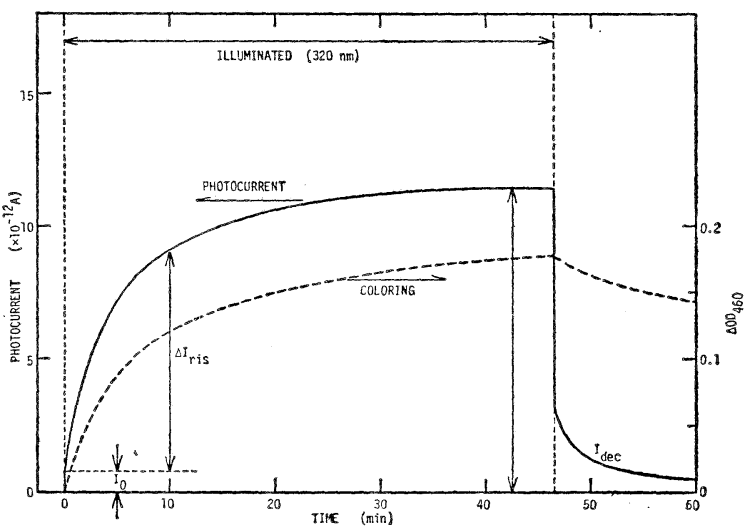

Fig. 2. Rise and decay curves of the photocurrent and the photo-induced optical absorption at $460 \mathrm{~nm}$ for $47.5 \mathrm{CdO} \cdot 47.5 \mathrm{SiO}_{2} \cdot 5 \mathrm{Na}_{2} \mathrm{O}$ photochromic glass with $1.69 \mathrm{~mm}$ thickness. $\triangle O D_{460}$ denotes the difference in optical density between the clear and colored states.
光電流の立ち上がり曲線は，照射開始と同時に非常に 速く立ち上がる成分 $I_{0}$ (初期光電流亡呼ぶ） と, 長い応 答時間をもつ成分 $\Delta I_{\mathrm{r} \text { is }}$ (時間依存光電流）からなり， 数十分後に定常值 $I_{\mathrm{s}}$ に達する. 着色は $\Delta I_{\mathrm{r} \text { is }}$ と良く似 た立ち上がりを示すが, 光電流が定常值に達した後にも わずかずつ増加している，照射を停止すると光電流の一 部は急速に消滅し, その後は残留光電流 $I_{\mathrm{dec}}$ が長時間 にわたって観察される。

完全退色ガラスの暗電流は室温では極めて小さく，今 回の実験の感度内では検出されなかった. 高温で測定さ れた完全退色ガラスの電気伝導度と温度の関係 ${ }^{9}$ を室温 まで外そうすると, 今回の実験の暗電流は $3 \times 10^{-18} \mathrm{~A}$ と見積もられる。図 2 では，それより6けた大きい光電 流が誘起されている.

励起光の波長が一定であれば， $I_{0}$ と $I_{\mathrm{S}}$ は励起光の強 度に比例する。したがって，異なった強度の励起光を用 いて测定された $I_{0}$ と $I_{\mathrm{s}}$ を, 単位強度当たりの值にし て比較することができる．また，1000 V までの範井で 光電流と印加電圧の間にオーム則が成立するので, 一定 值 $500 \mathrm{~V}$ で測定した.

\section{2 電極からのキャリアー注入之温度上昇の検討}

今回の実験では電極にも励起光を照射するので, 電極 の光電効果によって自由電子がガラス内に注入され, そ れが光伝導のキャリアーになっている可能性がある。こ の点を検討するために, 電極を遮光する実験を行った. もし電極から注入されるキャリアーが光電流に支配的に 寄与しているのであれば，両方の電極を遮光すると光電 流が大幅に減少し, 片方の電極を遮光すると印加電圧の 極性によって光電流が大きく変化することが予想され る. 事実, ごく弱い光伝導を示す $45 \mathrm{CdO} \cdot 55 \mathrm{~B}_{2} \mathrm{O}_{3}$ ガラ スでは，負側の電極を照射する場合にだけ検出可能な 大きさの光電流が生じる.しかし今回取り上げた 47.5 $\mathrm{CdO} \cdot 47.5 \mathrm{SiO}_{2} \cdot 5 \mathrm{Na}_{2} \mathrm{O}$ ガラスにはそのような現象は 観察されず, 光伝導の支配的なキャリアーはガラス内 で生じることが分った.

図 2 の時間依存光電流 $\Delta I_{\text {ris }}$ が生じる原因の一つと して, 励起光によるガラスの温度上昇が考えられる. そこで，ガラスの表面にフィルム状の熱電詨を貼りつ けて図 2 と同じ励起光を照射したが， $0.1^{\circ} \mathrm{C}$ の測定感 度内で温度上昇は認められなかった。仮に $0.1^{\circ} \mathrm{C}$ の温 度上昇によって図 2 の $\Delta I_{\text {r is }}$ が生じるとすれば, 光電 流はあり得ない大きさの活性化エネルギー（約 100

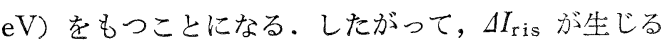
原因は熱的なものではないと結論することができる.

\section{3 フォトクロミズムの波長特性}

$47.5 \mathrm{CdO} \cdot 47.5 \mathrm{SiO}_{2} \cdot 5 \mathrm{Na}_{2} \mathrm{O}$ ガラスのフォトクロミ ズムに関する波長特性を，図 3 の（a）に示す。図中の $\mathrm{A}$ は, 約 $350 \mathrm{~nm}$ より短波長の紫外光によって誘起さ 


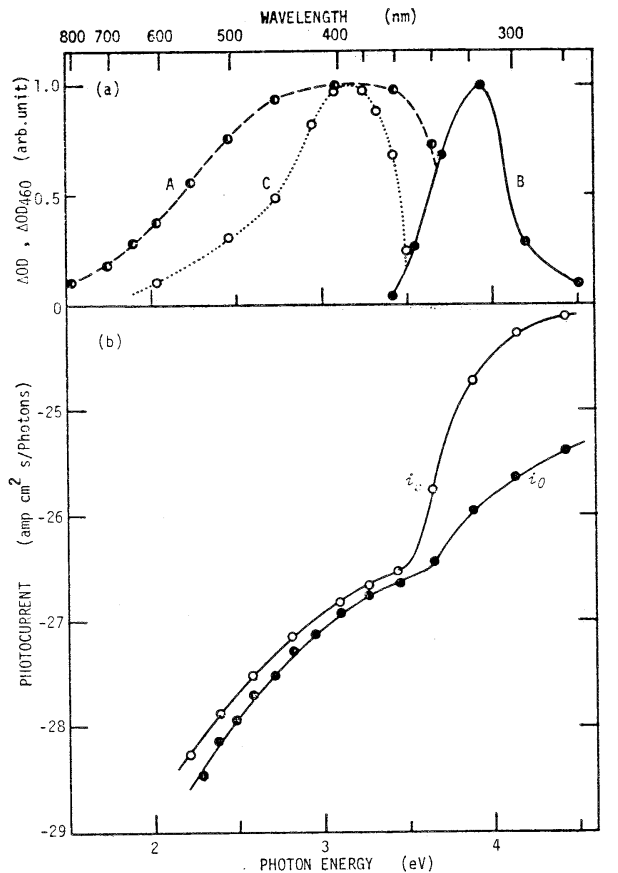

Fig. 3. (a): Photo-induced absorption spectrum indicated by the optical density change $\triangle O D(\mathrm{~A})$. Spectral responses of the photo-induced absorption (B) and the optical fading (C) indicated by $\triangle O D_{460}$.

(b) : Spectral responses of the photocurrent. $i_{0}$ and $i_{\mathrm{s}}$ denotes respectively the initial and saturated photocurrent per unit intensity of the exciting light.

れた吸収のスペクトルであり, 各波長における光学密度 の増加分 $\triangle O D$ で表した（着色スペクトル）， B は着色 の励起光スペクトルであり, それぞれの波長の励起光を 完全退色ガラスに一定エネルギー量だけ照射し，それに よって誘起される $\Delta O D_{460}$ で表してある. 着色したガラ スに可視光を照射すると, 退色が促進される (光退色) ${ }^{6)}$. 図 3 のC 係を表したものである. 一定に着色したガラスに一定エ ネルギー量の光を照射したときの $\Delta O D_{460}$ の減少分か ら, 暗中の自然退色の分を差し引いた值で, 光退色の大 きさを評価した．図 3 (a) から明らかなように，約 350 $\mathrm{nm}$ より短波長の光はガラスを着色させ，それより長波 長の光は着色したガラスの退色を促進する. そこで約 $350 \mathrm{~nm}$ より短波長の光を着色光, 長波長の光を退色光 と呼ぶ。

着色スペクトルの形（大きさではなく）の時間変化を 調べるために, 着色光照射下で着色が進んでいる段階 （着色過程）と暗中で退色が進んでいる段階（退色過程） の途中で, 着色スペクトルを測定した. それらのスペク トルを, 波長 $400 \mathrm{~nm}$ での $\Delta O D\left(\Delta O D_{400}\right)$ を 1 として

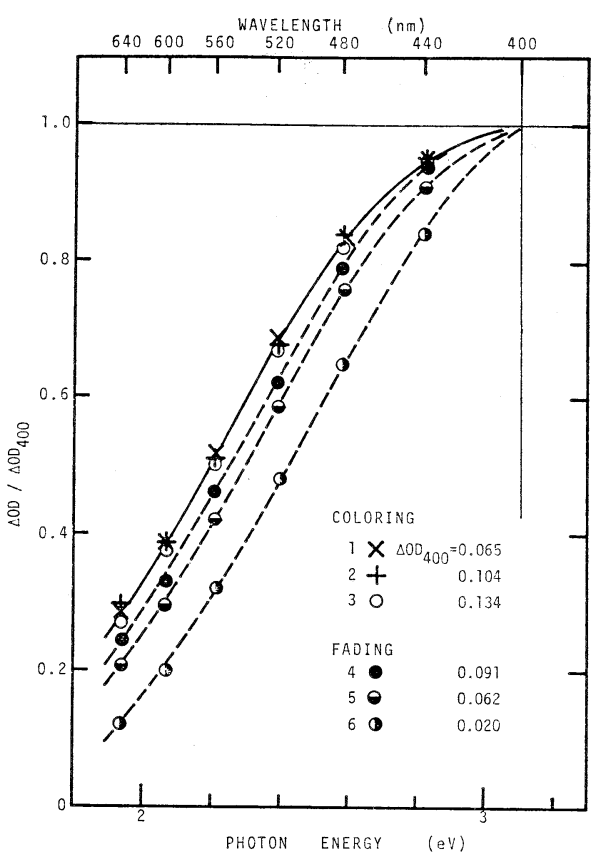

Fig. 4. Relative photo-induced absorption spectra in the coloring $(1 \sim 3)$ and fading $(4 \sim 6)$ process. $\triangle O D_{400}$ denotes the optical density change at $400 \mathrm{~nm}$.

相対的に表すと図 4 のようになる. 図中の $1 \sim 3$ は着色 過程, 4〜6 は退色過程のスペクトルであり, 数字の順 に着色または退色が進んでいる, 四から分るように, 着 色過程では着色スペクトルの形はほとんど変化せず，特 定の波長における $\triangle O D$ (例えば $\Delta O D_{460}$ ) の值でスペ クトル全体を評価することができる。これに対して, 退 色過程ではスペクトルの形が時間とともに変化し, 長波 長側ほど速く減衰する.

\section{4 光電流の励起光スペクトル}

図 3 の (b) は, 光電流の励起光スペクトルである. 図中の $i_{0}$ と $i_{\mathrm{s}}$ は, 図 2 の初期光電流 $I_{0}$ と定常值 $I_{\mathrm{s}}$ を励起光の強度 $\left(1 \mathrm{~cm}^{2}, 1 \mathrm{~s}\right.$ 当たりの入射光子数) で割 った值である。励起光の波長が短くなるとともに光電流 は増加し, 約 $350 \mathrm{~nm}$ より短波長の着色光領域で著しく 大きくなる. また, 着色光に対する光電流には非常に長 い応答時間をもつ時間依存光電流 $\Delta I_{\mathrm{r} \text { is }}$ (図 2) が現れ, $i_{\mathrm{s}}$ は $i_{0}$ の 10 倍以上に達する. これに対して, 退色光 による光電流は 1 分程度で定常值に達し， $i_{\mathrm{s}}$ は $i_{0}$ の 1.5 倍前後にすぎない.

光電流と着色の励起光スペクトルに対応して, 光吸収 端も $350 \mathrm{~nm}$ 付近から立ち上がる ${ }^{9)}$.

\section{5 着色, 光電流の立ち上がり曲線と着色光強度と の関係}

着色光の波長を一定とすれば着色の大きさ $\triangle O D$ には 相反則が成立し ${ }^{6)}, \triangle O D$ の值は着色光の強度 $L_{0}$ と照 
射時閒 $t$ の積の值によって一義的に決まる. 図 5 の A 各点は, 波長 $320 \mathrm{~nm}$ の着色光の強度を 3 段階に変えて 完全退色ガラスに照射した場合の， $\Delta O D_{460}$ と $L_{0} t$ の関 係をプロットしたものである（図中の実線については， 後の 4.3.2 項で説明する). 強度の異なった着色光に対 する. $\triangle O D_{460}-L_{0} t$ プロットが，良く重なり合っているこ とが分る.

時間依存光電流 $\Delta I_{\mathrm{r} \text { is }}$ にも, 着色の相反則と類似した 関係が見いだされる。図5のBは，Aと同時に測定され た $\Delta I_{\mathrm{ris}}$ を $\Delta I_{\mathrm{ris}} / L_{0}-L_{0} t$ の関倸にプロットしたもので

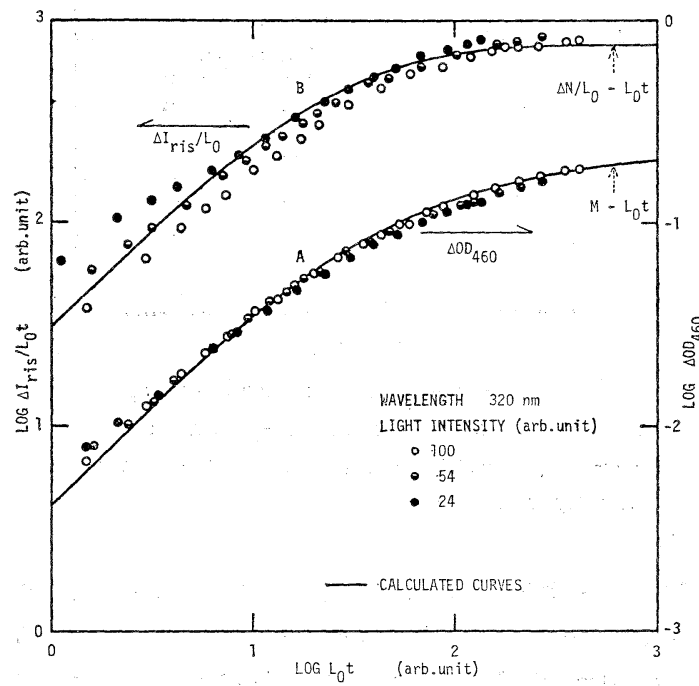

Fig. 5. Experimental points : $\triangle O D_{460}$ (A) and $\Delta I_{\mathrm{r} \text { is }} / L_{0}$ (B) as a function of $L_{0} t$ in the coloring process. $\Delta I_{\text {ris }}$ denotes the photocurrent with long response time, $L_{0}$ intensity of the coloring light and $t$ exposure time.

Solid lines: The calculated $\Delta N / L_{0}-L_{0} t$ and $M-L_{0} t$ curves with Eqs. (10) and (11).

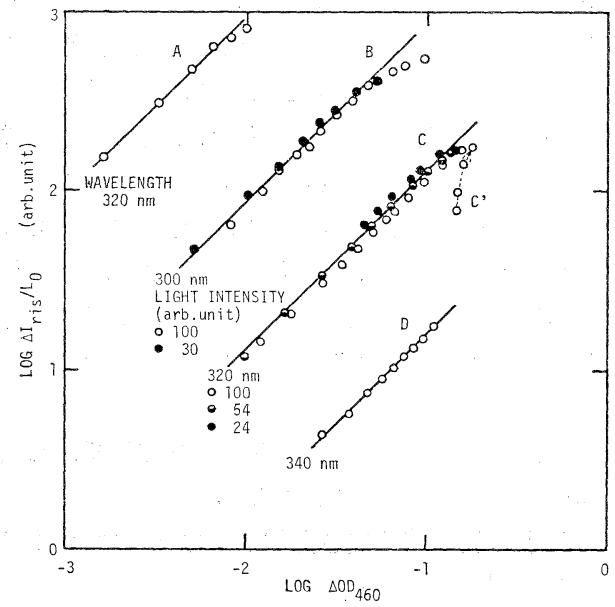

Fig. 6. $\Delta I_{\mathrm{ris}} / L_{0}$ as a function of $O D_{460}$ in the coloring process.
ある、Aに比べてばらつきは大きいが，異なった着色光 強度记対するプロットはだいたい重なり合っており， $\Delta I_{\mathrm{ris}} / L_{0}$ の値が $L_{0} t$ の值によってほぼ一義的に決まる ことが分る.

着色光の波長と強度を変えて図 5 の測定を行い，それ ぞれの着色光について $\Delta I_{\mathrm{ris}} / L_{0}$ と $\Delta O D_{460}$ の関倸をプ ロットすると, 図6のようになる。図中の実線は, $\Delta I_{\mathrm{ris}} / L_{0}$ と $\triangle O D_{460}$ が 1 次比例関係仙ある直線である. それぞれの着色光で, 定常值付近を除いて $\Delta I_{\mathrm{r} \text { is }} / L_{0}$ 泣 $\triangle O D_{460}$ に比例していることが分る。また，図中のB Cのように，波長は一定で強度が異なる着色光に対する プロットは, ほぼ重なり合っている.このように, 着色 光の波長を一定とすれば，定常值付近を除いて時間依存 光電流 $\Delta I_{\mathrm{ris}}$ は着色の大きさ $\Delta O D_{480}$ と着色光の強度 $L_{0}$ にほぼ比例する. 図から分るように, この場合の比 例係数注短波長注ざ大きい。ただし，これらの関係は， 完全退色ガラスに一定の波長と強度の着色光定常的に 照射する場合にだけ成立する. 例えば図6のCの実験 で，定常值に達したガラスをいったん暗中に置いてから 再照射すると，点線の矢印 $C^{\prime}$ に沿って定常值に戻る. その途中の段階では, 同じ $\Delta O D_{460}$ に対する $\Delta I_{\mathrm{r} \text { is }} / L_{0}$ はCの場合より小さい。

\section{6 着色したガラスの 2 次励起光電流}

着色したガラスに退色光を照射すると光退色が生じる が，光電流にも次のような現象が認められる。それは， 同じ退色光を完全退色ガラスに照射する場合よりずっと 大きな光電流が誘起されること，退色光の照射によって 図 2 の残留光電流 $I_{\mathrm{dec}}$ の隇衰が速まることで西る。こ

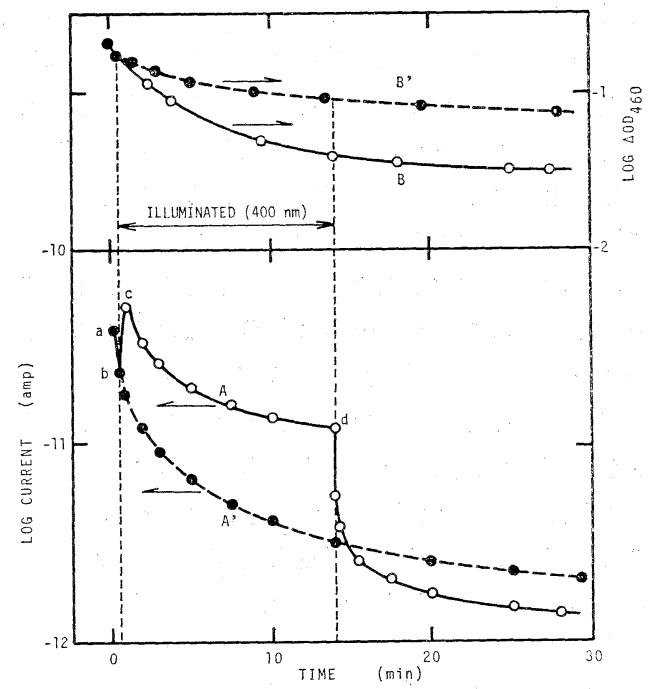

Fig. 7. Decay curves of the residual photocurrent $\left(A, A^{\prime}\right)$ and the photo-induced absorption $\left(B, B^{\prime}\right)$, in the dark ( $\left.A^{\prime}, B^{\prime}\right)$ and the illumination of $400 \mathrm{~nm}$ fading light for about 13 minutes (A, B). 
れらの現象の一例を図 7 に示す。図中の Aと B は，時間 ゼロで着色光を止めた後，図中に示した期間だけ波長 $400 \mathrm{~nm}$ の退色光を照射した場合の電流と $\Delta O D_{460}$ であ る.また $\mathrm{A}^{\prime}$ と $\mathrm{B}^{\prime}$ は, $\mathrm{A}, \mathrm{B}$ と同じ条件で着色したガ ラスをずっと暗中に置いた場合の電流と $\triangle O D_{460}$ であ る. A で $\mathrm{a} \sim \mathrm{b}$ は, 着色光を止めた直後の残留光電流 である. b で退色光を照射すると 2 次励起光電流が誘起 され，Cで極大に達した後に減衰していく. b と $\mathrm{c}$ の電 流の差は, 同じ退色光が完全退色ガラスに誘起寸る光電 流の約 10 倍になっている. d で退色光を止める之 2 次 励起光電流は急速に消滅して, 再び残留光電流だけが観 察される. この場合の残留光電流は，退色光を照射しな かった $A^{\prime}$ の約 70\% 、低下している。これに対応し て，B と $\mathrm{B}^{\prime}$ のように光退色が生じている.

\section{4. 考一察}

\section{1 光伝導よフォトクロミズムの機構}

一般に，絶縁体や半導体の光電導はバンド型の電子伝 導である. 3 章に示した $47.5 \mathrm{CdO} \cdot 47.5 \mathrm{SiO}_{2} \cdot 5 \mathrm{Na}_{2} \mathrm{O}$ ガラスの光伝導の性格には, 一般の光伝導と異なった伝 導機構を予想させるほど特異な点は認められない。 そこ でこの章では， $\mathrm{CdO}$ を含むガラスの光伝導がバンド型の 電子伝導であることを前提にして，実験から得られた結 果の解釈を試みる. 光伝導がバンド伝導であるならば, 暗中でも熱エネルギーによるバンド伝導が生じる注ずで ある. しかし，完全に退色した $47.5 \mathrm{CdO} \cdot 47.5 \mathrm{SiO}_{2}$. $5 \mathrm{Na}_{2} \mathrm{O}$ ガラスの瞕電流は, イオン伝導の性格を示す 9 . これはバンド伝導と同時に，それよりずっと大きなイオ ン伝導が生じているからであると考えられる。

図 3 のようにこのガラスの着色と光電流の励起光スペ クトルは良く対応して招り，約 $350 \mathrm{~nm}$ より短波長の光 （着色讯）によって顕著な 着色と光電流が同時に誘起さ れる。このことは，着色光による光キャリアーの生成 が，光電流だけではなく着色の原因にもなっていること を示唆している. 着色光による光電流には，図 2 の時閒 依存光電流 $\Delta I_{\mathrm{r} \text { is }}$ と残留光電流 $I_{\mathrm{dec}}$ の上うに，非常に 長以応答時間を持つ成分が観察される，一般に，光伝導 物質中で捕獲中心による光キャリアーの捕獲と放出が生 ヒる場合には，光伝導の応答時閒がキャリアーの寿命よ りずっと長くなることが知られている $\Delta I_{\mathrm{r} \text { is }}$ と着色の大きさの間には図 6 の上らな 比例関係が あり，また図 7 のうに着色したガラスに退色光を照射 すると $I_{\mathrm{dec}}$ の減衰と退色が同時に速められる。このよ うな現象は， $\Delta I_{\mathrm{ris}}, I_{\mathrm{dec}}$ と着色とが同じ原因で生じるこ とを示唆している。以上のような考察から，ガラス中に は何らかの捕獲中心が存在して拈り，それらが光キャり アーを捕えて一種の着色中心を形成することが，このガ ラスの着色の原因であると考えられる.
このような着色中心型のフォトクロミック物質として アルカリハライド, $\mathrm{SrTiO}_{3}: \mathrm{Mo}: \mathrm{Fe}^{12)}, \mathrm{CaF}_{2}: \mathrm{Gd}^{132}$ などが知られている。これらはいずれも結晶物質で亦 り，光キャリア一の捕獲中心を作るために，アルカリ蒸 気中での加熱をるいは不純物のドーピングなどの処理を されている、これに対して $\mathrm{CdO}$ 含有ガラスは，このよ らな特別な処理なしにフォトクロミック機能を持つ. 普 通の酸化物ガラスも，X線等の放射線を照射されると着 色することが知られている。がラス中には種々の欠楩が 存在して招り，これらの久陥が放射線によって生じた遊 離電子を捕えることが，この着色の原因であると考えら 礼ている. CdO.含有ガラスの場合にもこのようなガラ 又特有の欠宿が光キャリアーの捕獲中心になっていて, $\mathrm{CdO}$ を含んでいることは光キャリアーを生じさせる要 因であると推定される.

\section{2 バンドモデルによる定性的解䣋}

\subsection{1 バンドモデルの設定}

4.1 節の考察に基づいて，図 8 のようなバンドもデル を設定する. 光伝導のキャリアーは電子 (正孔でなく) とし，図中の $\mathrm{A} \sim \mathrm{D}$ の電子遷移が生じるとする。光吸 収端9) と光電流の励起光スペクトルはともに $350 \mathrm{~nm}$ 付 近から立ち上がるから，価電子带と伝導带の間のエネル ギー差は約 $3.5 \mathrm{eV}$ であり, 着色光はバンド間遷移を引 き起こすとする：価電子帯と伝導帯の閒には捕獲中心の 準位が存在するが，後の 4.2.4 項で述べる理由から，こ れらの準位はある幅に分布しているとする。このような バンドモデルを用いて，実験結果の定性的な解釈を以下 で試みる。

\subsection{2 光電流と着色の立ち上がり応答}

暗中に置かれた完全退色ガラス中には，自由電子も捕 獲中心に捕えられた電子(捕獲電子) む存在しない:こ れに着色光を照射するとバンド間骠移が起こって，伝導 帯に自由電子が生じる（図 8 A)，それぞれの自由電 子は光伝導に寄与した後, 再結合するか捕獲中心に捕え

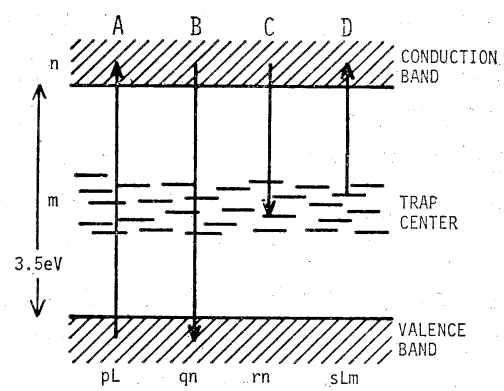

Fig. 8. A model for the photocurrent and the photochromism of the $\mathrm{CdO}$ based oxide glass. $n$ and $m$ respectively denotes the density of the free and trapped electrons and $p L, q n, r n, s L m$ the probability of the electronic transitions. 
られて消滅する $(\mathrm{B}, \mathrm{C})$. 自由電子を捕えた捕獲中心は, 可視域に吸収をもつ着色中心となる. 着色中心の捕獲電 子は熱あるいは光のエネルギーを吸収すると伝導帯へ再 励起され，その着色中心は消滅する (D). 照射開始の直 後では, 着色中心は極めて少ないから, 単位時間に゙Dの 遷移が生じる確率は $\mathrm{A}, \mathrm{B}, \mathrm{C}$ が生じる確率に比べて無 視できるほど小さい，そのため, 自由電子の寿命程度の 短い時間で，Aによる自由電子の生成と B, C による消 滅とが一時的な平衡に達する.ここまでが，図 2 の初期 光電流 $I_{0}$ として観察される.

その後は着色中心が個々には生成消滅しながら全体と しては増加していき, 捕獲電子の再励起によって生じる 自由電子も増えていく.この結果, 図 2 のように着色と 時間依存光電流 $\Delta I_{\mathrm{r} \text { is }}$ が同じ程度の時間変化率で増加し ていく. やがて $\mathrm{A} \sim \mathrm{D}$ の四つの遷移が平衡して, 光電 流と着色は定常值に達する. なお, 着色光照射下におけ る捕獲電子の再励起の機構については, 後の 4.2.4 項で 検討する.

\section{2 .3 減衰応答之 2 次励起光電流}

着色光を止めると, バンド間遷移と着色光による捕獲 電子の再励起（照射下でこの再励起が生じていたとすれ ば）が起こらなくなるから, 光電流は図 2 のように急速 に隇衰する. その後も残留光電流 $I_{\mathrm{dec}}$ が観察されるの は, 捕獲電子が熱エネルギーによって伝導帯へ再励起さ れるからである. 再励起された電子の一部は再び捕獲さ れるが他は再結合するから, 着色と残留光電流は時間と ともに減衰する.

退色光の光子エネルギーは，バンド間遷移を起こすこ とはできないが捕獲電子を再励起できる大きさを持つ. したがって, 着色したガラスに退色光を照射すると図 7 の上うに 2 次励起光電流が生じ, 残留光電流の減衰と退 色が促進される.

\subsection{4 着色光による捕獲電子の再励起}

着色光照射下で捕獲電子が再励起される際のエネルギ 一源としては, 熱のほかに着色光のエネルギーが考えら 杂る. 時間依存光電流 $\Delta I_{\mathrm{ris}}$ は捕獲電子の再励起によっ て生じるから,第 1 次近似として, $\Delta I_{\mathrm{r} \text { is }}$ は着色中心の総 数と 1 個の自由電子が再励起される確率に比例すると考 えることができる、実際，図6のように， $4 I_{\mathrm{r} \text { is }}$ 淀定常 值付近を除いて着色の大きさ $\Delta O D_{460}$ に比例している.

この $\Delta I_{\mathrm{ris}}$ と $\Delta O D_{460}$ との比例係数が捕獲電子が再励起 される確率に対応することになるが，図から分るように 着色光の波長が一定であれ标この比例係数は着色光の強 度 $L_{0}$ に比例し，また波長にも強く依存する．熱による 再励起の場合には, 捕獲電子が再励起される確率は着色 光の波長や強度には依存しないはずである.したがっ て, 着色光照射下では熱による再励起に比べてずっと大 きな比率で, 着色光による再励起が生じていると考えら
れる。

図 4 のように, 着色過程では着色スペクトルの形はほ とんど変化せず, 退色過程では着色スペクトルの長波長 側ほど速く減衰する. ガラス特有の構造の乱れを考慮し て捕獲中心ごとにその構造が少しずつ異なると考え，ま た前述のように着色光照射下では着色光による再励起が 支配的であるとすれば，この現象を以下のように説明す ることができる. 捕獲中心の構造の違いにより, 図 8 の ようにそれらのエネルギー準位にも差があり, また伝導 帯から見て浅い準位の捕獲中心ほど長波長側に吸収をも つ着色中心を形成する. 暗中では捕獲電子が熱再励起さ れる確率はそれが捕えられている捕獲中心の準位に強く 依存し, 浅い準位ほどその確率が大きい。このような結 果, 暗中の退色過程では着色スペクトルの長波長側に寄 与する着色中心ほど速く消滅することになる, 着色過程 でも熱再励起だけが生じているとすれば, 着色スペクト ルの長波長側ほど速く立ち上がるはずである. 一方, 着 色光はバンド間のエネルギー差よりも大きな光子エネル ギーを持つから，捕獲電子が着色光によって再励起され る確率は捕獲中心の準位に強くは依存しないはずであ る.したがって, 着色光照射下では着色光による再励起 が支配的であるとすれば, 着色過程では着色スペクトル の形がほとんど変わらないことを説明できる.

以上のように, 今回の実験の温度 (室温) と着色光の 強度の範囲内では, 捕獲電子が熱によって再励起される 確率より着色光によって再励起される確率のほうがずっ と大きいと結論することができる.

\subsection{1 分子反応型の速度式による定量的検討 \\ 4.3.1 速度式とその解}

この節では, 着色光照射下における図 8 の電子遷移が 最も簡単な 1 分子反応型の速度式に従うと仮定して, 着 色と光電流の立ち上がり応答を検討する.

自由電子の移動度を一定とし, 光電流の大きさはガラ ス中の自由電子の総数 $N$ に比例するものとする. また 着色過程では着色スペクトルの形は変化しないから, 特 定の波長における着色の大きさ $\triangle O D$ はガラス中の着色 中心の総数 $M$ に比例するとする. 着色光の吸収係数を $\alpha$, 入射強度を $L_{0}$ とすれば, 入射面から深さ $x$ の部分 に打ける着色光の強度 $L$ (内部強度) は次式のようにな る.

$$
L=L_{0} e^{-\alpha x}
$$

このようにガラス内の着色光の強度は一定ではないか ら，ガラス中の自由電子と着色中心の濃度も深さ $x$ によ って異なるはずである.そこで, 深さ $x$ のこころに十分 に薄い層を考え，この層に含まれる自由電子の数と着色 中心の数を層の厚さで割った值を, 哚さ $x$ における自由 電子の密度 $n$ 及び着色中心の密度 $m$ とする.

ガラス中の深さ $x$ の部分で, 図 8 の $\mathrm{A} \sim \mathrm{D}$ の電子遷 
移が単位時間, 単位厚さ当たり次の回数だけ生じるとす る.

\section{$\mathrm{A}$ : 着色光の内部強度 $L$ に比例}

$\mathrm{B}, \mathrm{C}$ : 自由電子の密度 $n$ に比例

$\mathrm{D}: L$ と着色中心の密度 $m$ に比例（着色光による 再励起だけが生じると近似)

この仮定により， $n$ と $m$ に関する次のような 1 分子反 応型の速度式が得られる。

$$
\begin{aligned}
& \frac{\mathrm{d} n}{\mathrm{~d} t}=p L-q n-r n+s L m \\
& \frac{\mathrm{d} m}{\mathrm{~d} t}=r n-s L m
\end{aligned}
$$

上式で $t$ 注時間, $p, q, r, s$ は着色光の内部強度には依 存しない比例保数である.

$t=0$ で $n=m=0$ を初期条件として（2），(3) 式を解 き，光の理由は後述するが， $q, r \gg s L$ と置くと, $n$ と $m$ の立ち上がり応答の式は次のようになる ${ }^{14)}$.

$$
n=n_{0}+\Delta n
$$

ただし

$$
\begin{aligned}
& n_{0}=\frac{p L}{q+r} \\
& \Delta n=\frac{p r L}{q(q+r)}\left(1-e^{-\frac{s q}{q+r} L t}\right)
\end{aligned}
$$

また

$$
m=\frac{p r}{q s}\left(1-e^{-\frac{s q}{q+r} L t}\right)
$$

$q, r \gg s L$ とした結果，(4)，(5) 式のように $n$ を構成 する 2 項 $n_{0}$ と $\Delta n$ のうち， $n_{0}$ の応答時間は事実上ゼ 口となっている。したがって， $n_{0}$ を図 2 の初期光電流 $I_{0}$ に, $\Delta n$ を時閒依存光電流 $\Delta I_{\mathrm{r} \text { is }}$ に対応させることが できる， $q, r \gg s L$ という条件は，1個の自由電子が再 結合あるいは捕獲される確率に比べて，1個の捕獾電子 が再励起される確率はずっと小さいことを意味する.

（1）式及び (4) ～(7) 式より，ガラス中の自由電子の 総数 $N$ と着色中心の総数 $M$ は次式のようになる.

$$
N=N_{0}+\Delta N
$$

ただし

$$
\begin{aligned}
N_{0}= & \int_{0}^{l} n_{0} \mathrm{~d} x=\frac{p L_{0}}{q+r} \int_{0}^{l} e^{-\alpha x} \mathrm{~d} x \\
\Delta N= & \int_{0}^{l} \Delta n \mathrm{~d} x=\frac{p r L_{0}}{q(q+r)} \\
& \cdot \int_{0}^{l} e^{-\alpha x}\left\{1-e^{-\frac{q s}{q+r} \exp (-\alpha x) L_{0} t}\right\} \mathrm{d} x
\end{aligned}
$$

また

$$
\begin{aligned}
M & =\int_{0}^{l} m \mathrm{~d} x \\
& =\frac{p r}{q s} \int_{0}^{l}\left\{1-e^{-\frac{q s}{q+r} \exp (-\alpha x) L_{0} t}\right\} \mathrm{d} x
\end{aligned}
$$

式中の $l$ はガラスの厚さである. 前述の仮定により， $N_{0}, \Delta N, M$ は, それぞれ初期光電流 $I_{0}$, 時閒依存光電
流 $\Delta I_{\mathrm{ris}}$, 着色の大きさ $\triangle O D$ に比例する.

\subsection{2 計算と実験の比較}

（9）式で $N_{0}$ は着色光の入射強度 $L_{0}$ に比例しており, 3.1 節で述べた, 初期光電流 $I_{0}$ が $L_{0}$ に比例するとい ら実験結果と一致する.(10)，(11）式で吸収係数 $\alpha$ と 比例係数 $p, q, r, s$ を一定とすれば, $\Delta N / L_{0}$ 及び $M$ は $L_{0} t$ の值によってそれぞれ一義的に決まる. 図 5 のよう に，着色光の波長を一定とすれ $4 I_{\mathrm{ris}} / L_{0}$ と $\Delta O D_{480}$ は $L_{0} t$ の值によってほぼ一義的に決まるから，上述の結 論は実験と合う．次に (10)，(11）式に適当な数值を入 れて $\Delta N-L_{0} t$ と $M-L_{0} t$ 曲線を計算すると，図 5 の実線 のようになる。 $\alpha$ と $l$ は図 5 の実線に合わせて $25 \mathrm{~cm}^{-1}$, $1.69 \mathrm{~mm}$ とした。 また $p, q, r, s$ の值は, $\Delta N / L_{0}-L_{0} t$ 曲 線が $\Delta I_{\mathrm{r} \text { is }} / L_{0}-L_{0} t$ 実験 プロットと, $M-L_{0} t$ 曲.線が $\Delta O D_{460}-L_{0} t$ 実験プロットとできるだけ良く一致するよ うに定めた．図から分るよらに，計算された $M-L_{0} t$ 曲 線は実験プロットとかなり良く一致し， $\Delta N / L_{0}-L_{0} t$ 曲 線と実験プロットもだいたい合っている.

以上のように，(8)〜（11）式は実験から得られた光電 流及び着色の立ち上がり曲線とかなり良く一致する。こ のような一致が得られた大きな要因の一つは, 着色光照 射下では着色光による捕獲電子の再励起が熱再励に比心゙ て十分に大きいと考えて，再励起の確率が着色光の内部 強度 $L$ に比例すると仮定したことである．仮に熱再励 起だけが生じているとすれば，速度式（2），(3) の右辺 最終項には $L$ が含まれない。そのような速度式から計 算される結果は，実験と全く合わない ${ }^{14)}$.

\subsection{3 ガラス内部の着色の分布}

この項では, 自由電子密度 $n$ と着色中心密度 $m$ に関 する (4) 〜 (7) 式から，主にガラス内の着色の分布に関 する幾つかの結論を引き出す.

着色光の入射面から深さ $x$ のとろでの単位厚さ当た りの着色の大きさを着色密度とし, 着色密度と $x$ の関係 をガラス内部の着色の分布と呼ぶ。着色密度は着色中心 の密度 $m$ に比例する。 $m$ に関する (7) 式を次のように 書き換える。

$$
m=m_{\mathrm{s}}\left(1-e^{-t / \tau}\right)
$$

ただし

$$
\begin{gathered}
m_{\mathrm{s}}=\frac{p r}{q s} \\
\tau=\frac{q+r}{q s L}
\end{gathered}
$$

(12)〜 (14) 式によれば， $m$ は $m(t=0)=0$ から時間之 ともに指数関数的に立ち上がり，定常值 $m_{\mathrm{s}}$ に達する. $m$ の立ち上がりは，時定数 $\tau$ が小さいほど速い。(13) 式の右辺には着色光の内部強度 $L$ は含まれないから， 着色光の波長を一定とすれば着色密度の定常值は $L$ に は依存しない。（13）式右辺で，バンド閒遷移の確率に 
関する定数 $p$ が分子に，捕獲電子の再励起に関する $s$ が分母に入っている。このことから分るように，Lが大 きくなっても $m_{\mathrm{s}}$ が変わらないのは, バンド間遷移が増 加する効果と, 着色光による着色中心の消滅が増加する 効果とが打ち消し合うからである．また（14）式のよう に, $m$ の立ち上がりは $L$ の増加に反比例して速くな る. 以上より，着色光の入射面から浅い部分ほど着色密 度の立ち上がりは速いが，定常状態ではガラスの内部は 一様に着色していることが結論される．ただし着色光の 吸收係数 が非常に長くなり, その部分の着色密度は普通の実験時 間内では定常值に達しない. 図 3 (a) のBのように, 今 回の実験では波長が $320 \mathrm{~nm}$ 付近の着色光によってガラ スが最も強く着色する。 $320 \mathrm{~nm}$ の着色光の $\alpha$ は 25 $\mathrm{cm}^{-1}$ であるから，実験に用いた厚さ $1.69 \mathrm{~mm}$ のガラ スの場合，透過面付近の $L$ は大射面付近の $1.5 \%$ 程度 の值を保持している. この着色光を直径 $1 \mathrm{~mm}$ 前後に絞 って長時間照射した後にガラスの側面から観察したとこ ろ, 前述の結論のと㧍り, 着色光が通った部分全体がほ ぼ一様に着色していることが確認された。いろいろな波 長の着色光に対する $\Delta O D_{460}-L_{0} t$ 曲線と（11）式とを比 較することによって，(12) 式の $m_{\mathrm{s}}$ と $て$ の相詨的な波 長依存性を求めることができる15)。その結果によれば, 着色光の波長が短くなるとともに着色密度の定常值は単 調に増加し，Lを一定とした着色密度の立ち上がりも速 くなる ( 励起光スペクトルが $320 \mathrm{~nm}$ より短波長で低下するの は， $\alpha$ が大きくなるために事実上ガラスの一部分しか着 色しないことが原因である。

自由電子の密度 $n$ のうち, 時間依存光電流 $\Delta I_{\mathrm{r} \text { is }}$ に 寄与する分は (6) 式の $\Delta n$ である. (6) 式と（7）式よ り,

$$
\Delta n=\frac{s}{q+r} L m
$$

となり, 深さ $x$ に扔ける $\Delta n$ は $x$ での着色中心の密 度 $m$ と着色光の内部強度 $L$ に比例する. (1) 式のよ らに， $x$ を決好 $L$ 洋着色光の入射強度 $L_{0}$ に比例 する。したがって，ガラス内部の着色の分布が同じであ れば， $\Delta I_{\mathrm{ris}}$ に寄与する自由電子の総数 $\Delta N((10)$ 式 $)$ は $L_{0}$ に比例する。図 6 のBあるいはCのように，異な った $L_{0}$ に対する $\Delta I_{\mathrm{ris}} / L_{0}-\Delta O D_{460}$ プロットが重なり合 うのは，着色光の波長が一定ならば，着色過程における ガラス内の着色の分布がガラス全体の着色の大きさ $\triangle O D$ の值だけで決まるからである。その理由を以下に 説明する．(12)〜(14) 式（あるいは（7）式）から分る ように， $m$ は Lt の值によって決まる. (1) 式により $L t$ は深さ $x$ と $L_{0} t$ の関数であり，また相反則により $\triangle O D$ は $L_{0} t$ だけで決まる.こうして, 結局 $m$ は $x$ と $\triangle O D$ の值によって一義的に決まるから， $\triangle O D$ が同じ 值であればガラス内部の着色の分布も同じになってい る。しかし，着色過程と暗中の退色過程とでは， $\triangle O D$ が同じであっても着色の分布は一般には異なる．着色中 心が熱エネルギーを吸収して消滅する確率はガラス内の 場所には依存しないから，仮りに着色光照射下でガラス 内が一様に着色していたとすれば，暗中でも一様のまま 退色してゆく.これに対して着色過程では,着色密度の立 ち上がりの速さは場所によって異なるから，定常状態に 達する前の着色の分布は一様ではない. 図6のCと $\mathrm{C}^{\prime}$ のように，着色過程と定常状態からいったん暗中に置い た後の再照射過程とで $\Delta I_{\mathrm{ris}} / L_{0}$ と $\Delta O D_{460}$ の関係が異 なる原因の一つは，上述の理由により C と $\mathrm{C}^{\prime}$ とでは $\triangle O D_{460}$ が同じでも着色の分布が違うことである。また， 図 2 のよら光電流が定常值に達した後化も着色がわず かずつ増加しているのは, 着色光の内部強度 $L$ が小さ いために $\Delta I_{\mathrm{r} \text { is }}$ にほとんど寄与しない深い部分で着色が まだ進んでいるからである.

\section{5. 総 括}

(1) $47.5 \mathrm{CdO} \cdot 47.5 \mathrm{SiO}_{2} \cdot 5 \mathrm{Na}_{2} \mathrm{O}$ フォトクロミック ガラスの光電流と光吸収を同一試料で同時に測定する実 験を行い，フォトクロミズムと光伝導の間に次のような 密接な関係を見いだした。

(1) 光吸収端に対応する約 $350 \mathrm{~nm}$ より短波長の光 （着色光）によって，顕著な 光電流と着色が 同時に誘起 される。

(2) 着色光による光電流には，非常に長い応答時間を もつ成分が観察される（立ち上がり応答における時間依 存光電流 $\Delta I_{\mathrm{ris}}$, 減衰応答に扔ける残留光電流 $I_{\mathrm{dec}}$ ). 着 色光の波長を一定とすれば，定常值付近を除いて $\Delta I_{\mathrm{r} \text { i }}$ は着色の大きさ $\triangle O D$ と着色光の入射強度に比例する.

(3) 着色したガラスに着色光より長波長の光 (退色光) を照射すると，同じ光を完全に退色したガラスに照射す る場合よりもずっと大きな光電流が誘起される (2 次励 起光電流)。また退色光の照射によって，退色と残留光 電流の減衰が同時に促進される。

（2）このガラスの光伝導が一般の光伝導と同様にバ ンド型の電子伝導であり，またガラス中に光電子を捕え る何らかの捕獲中心が存在すると仮定すれば，実験結果 を次のように説明することができる.

(1) 着色光を照射するとバンド間遷移が起こり，伝導 帯に自由電子が生じる。捕獲電子がこれらの自由電子を 捕えると一種の着色中心が形成され，ガラスは着色す る.

(2) 捕えられた電子（捕獲電子）が伝導带へ再励起さ れて時間依存光電流 $\Delta I_{\mathrm{r} \text { is }}$ が生じる. 着色光照射下で は，熱に比べて着色光による再励起が支配的である。こ 
の結果，第 1 次近似として, $\Delta I_{\mathrm{ris}}$ は着色の大きさ $\triangle O D$ と着色光の入射強度 $L_{0}$ に比例する.

(3) 着色光を止めた後にも着色中心から捕獲電子が熱 的に再励起されて, 残留光電流が生じる。退色光を照射 すると退色光によって捕獲電子が再励起されるから， 2 次励起光電流が誘起され，また退色と残留光電流の減衰 が同時に促進される。

（3）自由電子と着色中心の密度の時間変化率に関寸 る 1 分子反忘型の速度式を用いて, 着色と光電流の立ち 上がり応答を計算した．着色光照射下では捕獲電子が着 色光によってだけ再励起されると近似して計算すると， 計算結果と実際の立ち上がり曲線はかなり良く一致し た. 更に, この速度式から次のような結論が導かれた. ただし着色光の波長は一定とする.

(1) ガラスの内部では着色光の内部強度が大きい部分 ほど着色密度（単位厚さ当たりの着色の大きさ）の立ち 上がりが速いが，着色密度の定常值は着色光の強度には 依存しない。

(2) 着色過程では，ガラス内の着色密度と着色光の入 射面からの深さとの関係（着色の分布）は，ガラス全体 の着色の大きさ $\triangle O D$ の值だけで決まる.しかし, 着色 過程と退色過程とでは， $\triangle O D$ が同じで女ってもガラス 内の着色の分布は一般には異なる.

(3) ガラス内の着色の分布が同じであれば，時間依存 光電流 $\Delta I_{\mathrm{r} \text { is }}$ は着色光の入射強度 $L_{0}$ に比例する. また
$L_{0}$ と $\triangle O D$ が同じであっても，着色の分布が異なれば $\Delta I_{\text {ris }}$ の值も異なる.

謝辞 本研究を行うに当たり, 電子技術総合研究所材料 物性研究室の皆様に多大な御指導と御援助をいただきました。 ここに心からの感謝の意を表します。

\section{文献}

1) D.W. Strickler and R. Roy. J. Mater. Sci., 6, 20007 (1971).

2) G.S. Meiling, Phys. Chem. Glasses, 14, 118-21 (1973).

3) 熊田 虔, 山本和直, 並河 洋, 第 18 回窯業協会ガラス 部会討論会講演予稿集 (1977).

4）熊田 虔, 山本和直, 並河 洋, 窯協, 85, 359-66 (1977).

5）山本和直, 熊田 虔, 並河 洋, 第 18 回窯業協会ガラス 部会討論会講演予稿集 (1977).

6）熊田 虔, 山本和直, 並河 洋, 嚜協, 85, 359-66 (1977).

7）熊田 虔, 山本和直, 並河 洋, 第 18 回窯業協会ガラス 部会討論会講演予稿集 (1977).

8) K. Kumata, H. Namikawa and K. Yamamoto, J. NonCrystalline Solids, 34, 434-40 (1979).

9）山本和直, 熊田 虔, 並河 洋, 窯協, 88, 327-30 (1980).

10) R.H. Bube, "Photoconductivity of Solids", John Wiley \& Sons, Inc., New York p. 273-302.

11) C. Kittel, (宇野良清, 津屋 昇, 森田。章, 山下次郎共 訳) “固体物理学入門”, 丸善 (1974) p.638-39.

12) R. Williams, J. Appl. Phys., 42, 1131-35 (1971).

13) P.M. Heyman, Appl. Phys. Letters, 14, 81-84 (1969).

14) 山本和直, 職業訓練大学校紀要, 第 10 号 A, 15-22 (1981).

15）山本和直, 熊田 虔, 並河 洋, 職業訓練大学校紀要, 第 11 号 A, 11-19 (1982).

論 文・Paper

\title{
$\mathbf{E}$ ガラスと微量の水分の相互作用
}

\author{
作花済夫・神谷貴志・神谷寛一
}

(三重大学 工学部 工業化学科)

Eガラス（微量のアルカリを含むカルシウムアルミノホウケイ酸塩ガラス）の低温粘度に対する 微量の水分の影響を研究した. $1400^{\circ} \sim 1450^{\circ} \mathrm{C}$ の高温で溶融ガラス中に水蒸気を吹き込むか，その 雾囲気にさらすことによってガラス中の水分含有量を増し，また乾燥窒素を吹き込むか，その雰囲 気にさらすことによって水の量を減少し，水分含有量が $0.0014 \mathrm{wt} \%$ ～ $0.105 \mathrm{wt} \%$ の範囲のガラス

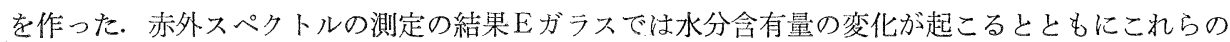
処理で $\mathrm{B}_{2} \mathrm{O}_{3}$ 含有量に変化が起こることが分った. したがってEガラスの粘度に対する水の含有量 の影響を明らかにするために， $\mathrm{B}_{2} \mathrm{O}_{3}$ 含有量の異なるガラス及びアルカリ含有量の異なるガラスを 作って粘度に対するそれらの含有量の影響を明らかにし，そのデー夕に基ゔく補正を加えた。 その

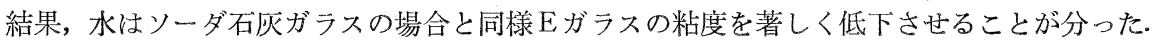

